University of Louisville

ThinkIR: The University of Louisville's Institutional Repository

Electronic Theses and Dissertations

$5-2017$

\title{
Building the bastard : confidence through preparation in Shakespeare's King Lear.
}

Shaleen Tarun Cholera

University of Louisville

Follow this and additional works at: https://ir.library.louisville.edu/etd

Part of the Acting Commons

\section{Recommended Citation}

Cholera, Shaleen Tarun, "Building the bastard : confidence through preparation in Shakespeare's King Lear." (2017). Electronic Theses and Dissertations. Paper 2640.

https://doi.org/10.18297/etd/2640

This Master's Thesis is brought to you for free and open access by ThinkIR: The University of Louisville's Institutional Repository. It has been accepted for inclusion in Electronic Theses and Dissertations by an authorized administrator of ThinkIR: The University of Louisville's Institutional Repository. This title appears here courtesy of the author, who has retained all other copyrights. For more information, please contact thinkir@louisville.edu. 
BUILDING THE BASTARD:

\author{
C2 1) ,' ( $1 \&(7+528 *+\mathrm{P} 5(3 \$ 5 \$ 7,21,1 \mathrm{~S}+\$$. ( 63( \$ 5 ( $66 \square K, 1 * L(\$ 5$ \\ by \\ Shaleen Tarun Cholera \\ B.A., The University of the South, 2009
}

\begin{abstract}
A Thesis
Submitted to the Faculty of the Colleges of Arts and Sciences of the University of Louisville In Partial Fulfillment of the Requirements for the Degree of
\end{abstract}

Master of Fine Arts in Theatre Arts

\author{
Department of Theatre Arts \\ University of Louisville \\ Louisville, Kentucky
}

May 2017 
Copyright 2017 by Shaleen Tarun Cholera

All rights reserved 



\section{BUILDING THE BASTARD:}



By

Shaleen Tarun Cholera

B.A., Tennessee, 2009

A Thesis Approved on

April 25, 2017

by the following Thesis Committee:

Dr. Russell Vandenbroucke

Dr. Janna Segal

Dr. Siobahn Smith 


\section{DEDICATION}

This thesis or dissertation is dedicated to my parents

Shila and Tarun Cholera

and

my daughter,

Valentine 


\section{ACKNOWLEDGMENTS}

I would like to thank my thesis advisor, Dr. Russell Vandenbroucke, for his guidance and patience through this thesis, and for making me a better writer. I would also like to thank my teachers: , Dr. Jenn Calvano, Professor Erin Crites, Professor Daniel Hill, Professor Rachel Hillmer, Professor Johnny Jones, Dr. Baron Kelly, Dr. David Landon, Corey Parker, Paulette Regan, Dr. Janna Segal, Dr. Amy Steiger, and Dr. Carol Stewart.

I would like to thank Dr. Siobhan Smith and Dr. Janna Segal, for volunteering their time, expertise, and knowledge to be part of my committee.

Professor Nefertiti Burton deserves to be singled out for her unparalleled support of all graduate students throughout my time here.

Also, without Tyler Madden, Paula Lockhart, Danielle Smart, and Casey Moulton I

would not have "learned, laughed, or lived as well through graduate school as I have had the privilege to.” (Moulton, iv) 


\begin{abstract}
BUILDING THE BASTARD:

C2 1 ) ,' ( $1 \&\left(7+528 *+\mathrm{P} 5\left(3 \$ 5 \$ 7,21,1 \mathrm{~S}+\$\right.\right.$. ( 63( \$ 5 ( 66 K,1 ${ }^{*} L(\$ 5$

Shaleen Tarun Cholera
\end{abstract}

April 25, 2017

This thesis is to chart my discovery that confidence is essential to an actor's craft. This thesis focuses on my performance as Edmund in King Lear, as well as my production the previous summer playing Hussein in Ayad Akhtar's Disgraced. I draw from a variety of sources, such as meditation and formal acting exercises, to achieve confidence. Most importantly, I distill my missteps as an actor for a better understanding of what hinders confidence when building a role for performance. 


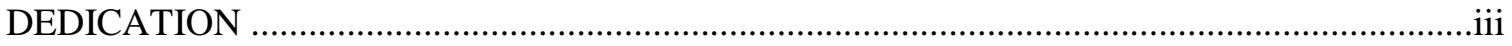

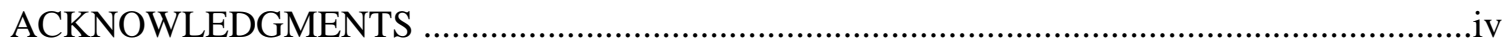

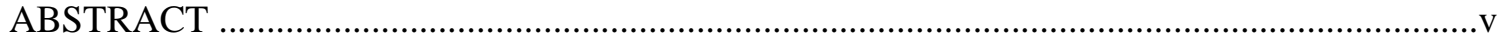

LIST OF FIGURES................................................................. vii

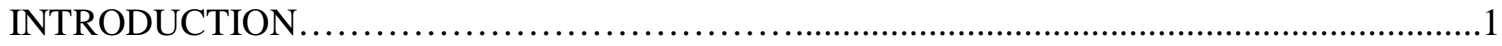

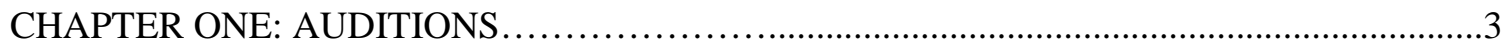

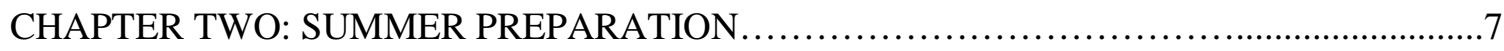

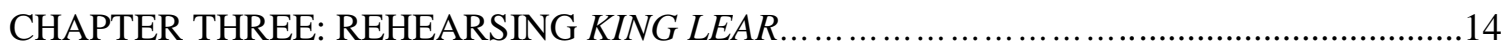

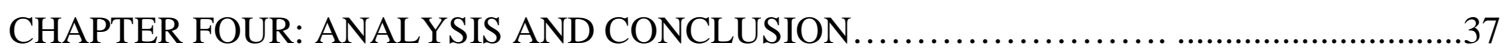

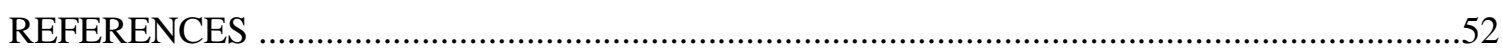

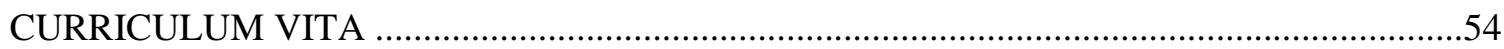




\section{LIST OF FIGURES}

PAGE

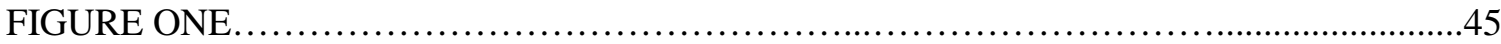

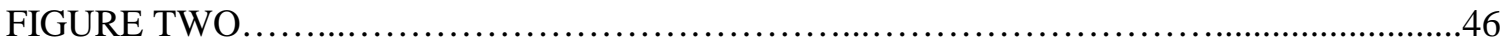

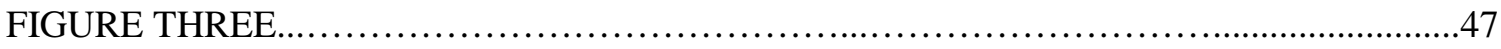

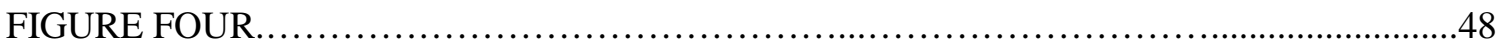

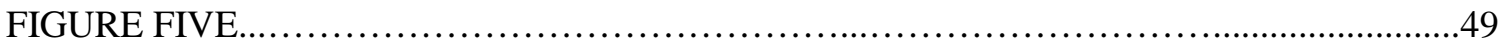

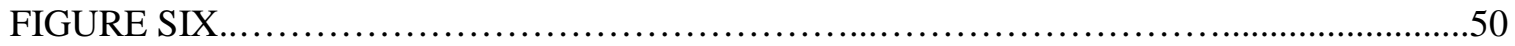

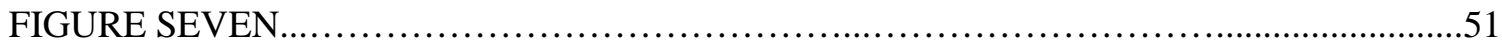




\section{INTRODUCTION}

This thesis describes the progress of a twelve-year journey that still has not culminated.

The goal was, and always will be, to be the best actor I can be. True, this marks the end of a specific part of that journey (compromising exactly three years, or twenty-five percent), but the path never ends, merely twists and diverges. My endeavor began as an 18-year old senior in high-school, but I will focus on my craft developing in one specific role: Edmund in William Shakespeare's King Lear. I will detail how I approached the role pre-rehearsal, prepared during rehearsal, reflect on my performance during and after, and in a final section, discuss how to further my craft.

I struggled mightily to begin writing this thesis, thinking to myself, "What, exactly, is the point of an actor detailing a process?" or "That's not a thesis, that's a performance report." And, truly, a large part of this will constitute a performance report from the point-of-view of an actor, but upon reflection, realize this thesis is much more than a performance report.

When I began graduate school, I had one primary goal: To leave with my own, solid "technique" that I could apply to any acting role. That was it. I had many secondary and tertiary goals, but the primary one was always to acquire the necessary tools and skills needed to approach a role and present a complete, well-rounded, dynamic, and believable character to the audience. I knew exactly why I was going to school and what I wanted the skills for after I graduated: to be able to act Shakespeare at a high, and eventually the highest level, a simple goal, but a monumental task. I fell in love with the 
playwright's works at a young age, and most of my stage experience has been in plays such as A Midsummer Night's Dream, Macbeth, Othello, Romeo and Juliet, and more.

Out of the pursuit of that goal, came the genesis of this thesis and my personal approach to the task. It details my personal technique to approaching the emotional and technical challenges and demands when performing roles. It is my own technique that I can continue to perfect. It is a technique that can be adapted to approach modern texts, abstract texts, really, almost any dramatic text. However, where it works best is with William Shakespeare because a large part of the technique derives from books on Shakespearean acting: The Actor and the Target by Declan Donnellan, and Playing Shakespeare by John Barton. Other books such as The Second Circle by Patsy Rodenburg and Script Analysis for Actors, Directors, and Designers by James Thomas help the technique be adapted to other texts. It is not perfect by any means, and needs constant practice, performance, and revision. Nothing can replace practice and performance.

In retrospect, all exercises contained in the technique contribute to one goal: To give me confidence when performing. For me, confidence leads to exuberance on stage. Acting teacher Robert Cohen defines exuberance as "performance level energy combined with a positive and uncritical attitude” (Cohen 9). Cohen also says that exuberance allows the audience to have empathy for the character, which:

carry the audience along...a character's enthusiasms are the points of audience contact; they determine the elation we feel when the character succeeds and the poignancy we share when the character fails. (53-54)

Thus, confidence helps both actors as well as the audience have an enjoyable experience. 


\section{CHAPTER ONE}

\section{AUDITIONS}

Two mentors, both of whom have played the titular character in Lear, have told me they see me cast as Edgar, yet I have always felt attracted to the role of Edmund for the opposite qualities he has from me, such as deviousness and maliciousness. When approaching Edmund, I started by doing character research for auditions the spring before the fall production. I am a strong believer in feeding the "well” to draw from with the “food” of viewing live performances and films, and reading performance critiques, character analyses, and so on. I had previously seen two productions of the play, and found Edmund to be a witty and engaging character that I would enjoy playing. Between the sons of Gloucester, I found him to be the more interesting. Thus, I began preparing my audition.

Early research included an article in The Montreal Review by Race Capet titled "It's New Mother Nature Taking Over: A Re-Reading of Edmund in Shakespeare's King Lear." Capet helped in many ways: It was my first encounter of someone linking the vivid iconography of nature to Edmund in a scholarly fashion (Capet 1), it set the blame of Edmund's scheming squarely on Gloucester's shoulders rather than Edgar's (Capet 5), it pointed out the particularly derogatory language used to refer to Edmund's status, however casually and innocently (Capet 6), and it presented a sympathetic view of Edmund where most productions I had seen typically cast him as a smarmy villain. Capet's overall conception gave Edmund more depth than how I had seen him portrayed 
and thus more to play with as an actor. This was one of the earliest and most helpful pathways I found into performing Edmund.

One of the earliest clues about Edmund I gleaned from Capet was that he was repeatedly linked to nature. This strong relationship gave me something to explore, namely, the color green and its emotional effect on my acting. Much of acting is metaphysical and inspiration may come from the strangest places. My approach towards inspiring material has always been to throw as much as possible into the proverbial pot initially, and then see what the core ingredients are that speak strongest to me as the process proceeds. I began playing with some exercises I had learned from a teacher, Corey Parker. Parker suggested actors keep a journal for each role they played in which they could paste pictures, write poetry, draw, and do other such exercises to inspire creative thought about their characters. I began to curate material from every source available that said "nature" to me. It did not matter what it was, it all went into a large folder that was my repository for inspirational material throughout the Lear rehearsals. Eventually, with closer inspection of the text and further refinement, pictures of bears, jaguars, and 19th-century French soldiers wound up in the journal, but initially most of the material focused on the concept of green and what it meant to me. The color suggested such concepts and words as: growth, active, masculine, feminine, virility, Darwinian, Machiavellian, and divine. These initial impressions were of much value later in the process, especially when it came time to work on Edmund's physicality. They were also particularly helpful for my audition because they sparked my imagination.

The day of my audition I was extremely nervous. I had not prepared enough by my standards. I had only worked on my monologue for about ten days, when I typically 
need at least two weeks. I made a gamble and sacrificed "floor-work" time, what I call that time crafting a performance on my feet, for research. I vamped with the director, Jennifer Pennington, by discussing the different versions of Lear. Eventually, my nerves settled and I did my monologue. I remember feeling okay with my audition. I tried to take advantage of the space, but I do not think I nailed the monologue, Edmund's famous “Thou, Nature, art my Goddess” (1.2) soliloquy.

Pennington gave me some direction, namely to play up the enjoyment of evilness within Edmund, and to lessen the angst behind his motivation. I had spent quite a bit of time with Capet's article, which presented Edmund more sympathetic emotionally, and so I had prepared a softer and more justified Edmund. Pennington was now giving me the opposite direction, and after a few more seconds of questioning her to sort my thoughts, I made what I thought were the adjustments requested. She again asked me to dig in deeper. I began to get nervous again. However, the second time Pennington exclaimed "Yes! That's exactly what I meant!" and my nerves settled. I was very proud I was able to make such a large adjustment so quickly. The previous two years of training were paying off. I left feeling that I had given the audition my best, with what I had time to prepare, while still having fun. I found out a few weeks later I had been cast as Edmund. I was ecstatic. This was a great role that would allow me to expand and have fun, which is hard to come by. I soon found out that my college mentor, Dr. David Landon, would be appearing in the title role of the Nashville Shakespeare Festival's production of the same play. Knowing that Dr. Landon was aging and that this might be the only time I would get to see him act again, I decided to visit Nashville to see the production. I would also benefit from seeing a live production to see how the text came to life. Many people 
believe that actors should not view productions of a play they are rehearsing, but since this would not start for another six months, I felt okay going to see this one. My classmate Tyler Madden and I drove down to view the show, and we left enchanted. Dr. Landon did the role great justice, and the viewing helped me see how the play's arc functioned in a different way than a recorded production. I had only seen it live once before, and it was before much of my education as a Shakespearean actor, so I was not as able to see the "guts" of the production as I could this time.

One of the biggest details I noticed was that Edmund is extremely active in the first half of the play while he disappears largely in the second. I filed this away for further exploration. Already I wondered how I would handle the long gap between his appearances. I was slightly disappointed with the actor who played Edmund, but left extremely impressed by the actor playing Edgar. Edmund seemed too shallow, the typical smarmy, mustache-twirling caricature. I wanted to avoid that interpretation for our production, and I was convinced my previous impression was correct: Edmund was much deeper than the way I had seen three actors play him. This conflict between my impression of Edmund and others was to resurface during rehearsals. 


\section{CHAPTER TWO \\ SUMMER PREPARATION}

\section{Checking My Progress}

The summer gap between spring of 2015 auditions, and the fall production ended up being invaluable; it allowed me to "test drive" the technique I had been building for two years with the role of Hussein in Ayad Akhtar's Disgraced at Playhouse on the Square, a regional-theatre in Memphis. I planned to test the technique so that I would have a clear idea what I needed to work on during rehearsals for Lear.

The role of Hussein became incorporated into Edmund for two reasons: Hussein is a college student, and I would have to change physically to portray him as I envisioned him. I would have to lose weight. This aligned with the mental image I had of Edmund, which was fortunate because I would need all the time I had to achieve this goal since I had just gained weight for my previous performance of Lincoln in Suzan-Lori Parks’ play Topdog/Underdog. The second reason was that Hussein would allow an important assessment of my craft after two years of graduate school. I also decided to hire my old acting coach, Corey Parker, to give me critical feedback. This, along with new acting exercises I explored while rehearsing Disgraced, ended up contributing greatly to my performance as Edmund.

Since I imagined Hussein as approximately ten years younger than me, I wished to lose weight to believably play a younger character. Even though an actor's physique is more apparent on film, I believe in changing my physicality as much as possible to play a 
role. I also think it is important for an actor to know about nutrition and exercise since our business includes physical appearance, and demanding movement requires an athletic body. Standing 5'8" and weighing 177 lbs., I was far from the metabolically-active college student I imagined Hussein to be. However, I did not see him as particularly "fit" (having a healthy or better fat-to-muscle ratio, along with a healthy degree of cardiac fitness). In my mind, he was an average, a college student who wakes up and does not think twice about eating sugary cereal for breakfast and wasting a day on the couch playing video games. Physical fitness was simply not one of the character's priorities, but being youthful, I still imagined him being skinny. I ended up losing seventeen pounds over the course of the summer, mainly through diet and cardio-based exercise. I had been what might be described as "skinny-fat”: my weight was within accepted medical guidelines, but with a poor fat-to-muscle ratio. Losing excess weight also gave me a solid foundation of fitness from which to add muscle for the role of Edmund, which I felt was important for an accurate portrayal of him.

Still more important were the discoveries I made reading Declan Donnellan's The Actor and the Target. The book rearranged my viewpoint on acting by distilling the Stanislavski principles into a set of rules that other books had not. I originally picked up the book because I had heard great reviews of it from former colleagues, and I wanted to expand my knowledge of acting approaches as much as possible before my thesis role.

Donnellan is an English director who co-founded the company Cheek By Jowl. In addition, he has directed other major theatre companies, most notably the Royal Shakespeare Company and the Moscow Art Theatre, and films. In 2002, an English reworking of his Russian book, The Actor and the Target was published. It is both a 
philosophical text on acting and a resource that helps actors who already have some understanding of their craft get over specific problems they frequently encounter during rehearsal. For my ability, it was perfect. I had cobbled together a way to approach different roles, and what I needed was guidance at a higher level dealing with very specific technical problems.

In his book, Donnellan first muses on what he believes acting to be and how an actor should approach his/her craft. He then addresses specific problems commonly faced by actors in rehearsal. The book's central thesis is that value judgements such as "good" and "bad" do not truly exist among artists of a certain caliber. Rather, there are simply artists who are "less blocked" or "more blocked" (Donnellan 6). During the rehearsal process, it is the actor's job to identify and remove blocks. The way Donnellan explained his approach resonated deeply. It redirected anxious energy stemming from my desire to produce, while helping do just that: produce quality work. I felt like I could apply Donnellan’s technique to Disgraced, and also to King Lear.

Donnellan's list of common blocks was particularly helpful because they were the same ones I encountered as an actor that no director or teacher had suitably addressed. These include: “I don’t know what I’m doing,” “I don’t know what I want,” “I don’t know who I am,” “I don’t know where I am,” “I don’t know how I should move,” “I don't know what I'm feeling," "I don't know what I'm saying," and “I don’t know what I'm playing.” Donnellan dedicates a chapter to each of these blocks, with exercises and approaches to dissolving each one. Many of them could be solved just by changing my mindset, usually by relieving some unnecessary pressure I was putting on myself. 


\section{What Worked and What Did Not: Reviewing the "Test-Drive"}

I used Donnellan's book to tackle Hussein in Disgraced. It helped immensely, but did not fix all my problems. I still had one major moment of difficulty: my director asked me to cry on cue, and she structured the delivery of a monologue for me to do so. Typically, such line readings or forced direction is frowned upon, and I was unprepared for it. However, I dove headfirst into uncertainty to give my director what she wanted. It was important to me, going into my final year and about to undertake my thesis role, to be prepared to handle whatever direction Pennington might give me later.

I did not land that difficult moment in a way that measured up to my standards more than once or twice, and I kept tinkering with it through the run: I meditated backstage before the show and whenever I was backstage, which gave me total focus for the climactic moment, helping me be present. Also, leading up to it, I prepped myself emotionally by listening to music backstage and looking at photographs that resonated with me emotionally. At first, I tried sad photos, but it was joyous ones that really awoke my emotions. I would look at these photos and just be present with them, which also seemed to help for a few days. After a couple of performances, the effect vanished, and I decided the exercise was valuable, but not the most effective way of evoking the vulnerability required. In the end, focusing on "basics,” like what I wanted from my acting partners, listening, and thinking of what objective I was playing, was what helped most. I would revisit a similar moment of trying to make an emotional reaction believable during Lear when trying to play Edmund's moment of salvation at the end credible. 
One of the biggest benefits during Disgraced was the incorporation of meditation, specifically Zazen and Mindfulness meditation. During the summer, my personal life turned worse, and I had trouble focusing in rehearsals and on stage. I have practiced meditation for nine years, and have even taught mindfulness meditation in a formal setting. However, I had never incorporated it formally into my acting technique. I had previously noticed some side effects on stage, such as increased focus, less selfconsciousness, and the ability to invest myself "in the moment," but these were residual benefits to the practice. I had never meditated specifically for acting. But, something told me the time was right to incorporate meditation into my work. I developed a threefold meditation practice to center myself before each performance. I practiced this daily during Disgraced so that I would be prepared to retain it during King Lear. Meditation, like any other discipline, wanes without regular practice. My meditation technique was the following:

1. The first section was centered around Jon-Kabat Zinn's mindfulness exercises, meant to bring focus to the body, the breath, the five senses, and emotions that were present "here" and "now." This lasted approximately ten to fifteen minutes. Once a sufficient level of awareness had been achieved, I would transition into the second meditation section.

2. The second section was more Zazen based. I would clear my mind of all stimuli and awareness and focus exclusively on my breath. Eventually, this would slowly dissipate, leaving me with a wonderful sense of stillness and presence. This section would also last approximately ten to fifteen minutes. 
3. The third and final section was a guided-meditation I developed on my own. It was based in mantra meditation as well as visualization exercises that many sports psychologists recommend for athletes. Basically, I would give myself images to ground me and give me confidence. An example would be roots emerging from the core of the earth that slowly grew towards and into my feet, and up my spine, giving me energy from which to draw. I would envision the troublesome parts of the play and envision me executing the acting precisely. I would imagine a green light filling my body as nature gave me power. I would then repeat a few mantras designed to boost my self-confidence, that all important ingredient for actors, and remind myself to have fun on stage. This would last approximately ten minutes and would end about a minute before I went on stage. This final minute allowed me to "drop" all my preparation, clear my mind, and focus on my partner. This was the most important step of all.

Meditation allowed me to finalize my acting process in a very interesting way. Through Zazen, I could get to the next level that many actors talk about: dropping all the preparation and just having fun in the moment. In the past, I would prepare and rehearse, and then go on stage trying to accomplish the goals I had set for my character during rehearsal. However, this approach seemed forced. I was thinking too much on stage, and even if the audience could not see this, I felt like they instinctively knew it. Meditation allowed me to drop all the worrying about accomplishing my rehearsal preparation, and simply focus on being in the moment as the character. It allowed me to stop worrying about my rehearsal preparation. It simply let me "be" on stage. From this state, I naturally pursued the goals my character wanted and the rehearsal prep came through. It was a very exciting feeling the first time I was not "doing" anything on stage. 
The final preparation over the summer was feedback from my old acting coach, Corey Parker, about my performance in Disgraced so that I could improve for Lear. He observed that my work on the "fourth wall" was weak and not specific enough. By ignoring this, I was avoiding looking into the audience, which diminished my energy. That was a major issue in live theatre, he said, where the intermingling of the audience's energy with the performers elevates the performance overall. I vowed not to let this happen with Edmund, especially because he frequently breaks the fourth wall and addresses the audience directly. I would have to find a way to make this transition seamless.

It was not until the very end of the summer that I realized Donnellan's book was written specifically for Shakespearean actors and texts. Having applied Donnellan’s rules to a modern play such as Disgraced, I felt especially confident that I would be able to apply them to King Lear. Now that I was in shape and had test-driven the jumble of acting techniques I had just learned over the past summer and previous semester, I felt more prepared than ever to take on Edmund. 


\section{CHAPTER THREE \\ REHEARSING KING LEAR}

\section{Working Out for Edmund}

Back at school, I continued to change my body to fit the role of Edmund. This would require me to tweak my diet and activities to achieve my desired results: replacing fat with muscle. Pennington stated in one of the first rehearsals that she decided Edmund was a soldier in Lear's army. He successfully leads an army into battle against France, showing considerable military prowess, which I imagined came from his training. Letting Pennington's idea of Edmund as a trained soldier percolated in my brain. I thought he would be much more physically developed than a modern-day college student like Hussein after years of learning military skills such as horseback riding, physical combat, and proficiency with weapons. These changes were not observed closely by the audience, as they would be on film, so to the average patron the physical changes were hardly noticeable. However, the confidence and commitment I gained in changing my body from its habitual state to fit a character was well worth the effort.

I was then very skinny with little muscle tone due to the summer's heavy emphasis on cardio-based exercise with almost no weight-based resistance training. Scientifically, it is impossible to gain muscle without increasing caloric-intake, but I had no desire to gain weight. I wanted to swap fat for muscle, the holy grail of exercise. Due to the short amount of time, and my limited knowledge of nutrition and exercise science, 
I settled for maintaining my body weight via diet and cardio exercise, while lifting progressively heavier weights, which would at least define my muscles more while shedding excess fat. I also tweaked my diet to remove almost all carbohydrates, which sped up the fat loss. I focused on large, compound lifts that worked the major muscle groups to maximize my preparation time.

The results were good: I dropped around four percent of my overall body fat, while losing five pounds in addition to the initial seventeen.

\section{Bringing Edmund's Text to Life}

The first step for me as an actor is to read the script and hunt for clues about the character. I had done some light research during auditions as noted above, but I now returned to the script with a closer eye. It was here that I reviewed James Thomas's Script Analysis for Actors, Directors, and Designers. It is the best book on script analysis I have encountered. Thomas leads readers through all elements of Aristotelian script analysis and demonstrates how to dig into a text to use seemingly innocuous observations to justify bold and exciting acting choices.

When reading Lear with Thomas’s precepts in mind, I noticed characters referring to Edmund as “whore-son" in his presence and using the term as an insult throughout the play. Also, the text implies that Edmund fell into his fortunes: he did not begin the play with a goal to end it as a king. Originally, his plan was just to disenfranchise his brother. Another clue I found was from a close reading of Gloucester's text when describing Edmund's birth and heritage:

His breeding, sir, hath been at my charge. I have so often blush'd to acknowledge him, that no I am braz'd to't" and "Though this knave came something saucily to the world before he was sent for, yet was his mother fair, there was good sport at his making, and the whoreson must be acknowledg'd. (1.1, emphasis mine) 
These and other clues led me to choosing an overall objective for Edmund. I broke down every scene Edmund appeared in, and determined his scene objective for each. Next, I looked at them together to find an overall objective that tied them all together. I decided on a few overall objectives to try in rehearsal, eventually choosing "to be loved.” It was here that I erred, for this is not a playable goal, but a desire. According to Thomas, a piece of advice that I initially neglected is a playable goal requires the actor to phrase an objective it in the form of "I want to [verb] in order to [statement of purpose]." The active verb in the sentence makes the goal "actable”. However, in early rehearsals, I proceeded with the goal: "to get love, by any means necessary."

This gave me an arc for Edmund's journey: He begins the play desperately looking for his father's love, and he starts to take it, by whatever means he has. This extreme desire to be loved possesses him and make him ambitious for nothing less than the crown, which is ultimately his downfall. I also began breaking down each Edmund scene into playable "beats," and began to try different tactics. Through this trial and error, I made my acting choices.

Having chosen beats that built into scenes that built into an overall arc for Edmund, I still had the technical demands of Shakespeare's text. Shakespeare is a poet, and speaking his text requires awareness of how poetry and language works. Words are specifically chosen to reveal the inner emotions of the character, therefore nothing can be casual. Three books helped with the craftsmanship required for a performance of Shakespearean texts: Neil Freeman's annotated First Folio of King Lear, his annotated book of monologues Speak the Speech!, and John Barton’s Playing Shakespeare. 
Freeman's annotated versions of the 1623 First Folio are now widely used. I first learned the importance of using the First Folio when working with the Tennessee Shakespeare Company in Germantown, Tennessee. It used Freeman’s Folio texts as rehearsal tools, comparing them with modern editions because according to Founder and Artistic Director Dan McCleary, the Folio “is the closest we can come to what perhaps Shakespeare created and saw on stage.” (personal email, 2010) McCleary advocated that actors use whatever tools help them create a compelling performance, and one way to do so was to compare the Folio to modern editions of the plays.

Comparing different editions of Shakespeare is valuable for an actor. Freeman's edition of King Lear and his book of monologues, Speak the Speech!, which has a “modern” edition of every Shakespearean monologue side-by-side with the First Folio edition permits easy comparison. Poetical intentions such as rhythm and intensity can become clear doing this exercise because many modern editors “fix” Shakespeare’s punctuation, unknowingly erasing many acting clues.

After gleaning such rich clues from the text, I now felt obligated to bring the poetry off the page. I went to John Barton for instruction. Barton is an English theatre director, associated with Peter Hall and the Royal Shakespeare Company. His seminal work, "Playing Shakespeare" is still used by universities across the world to teach Shakespearean acting, including the University of Louisville.

Barton gives some simple advice for actors when approaching Shakespeare's texts. His advice can be followed for any text, Shakespearean or not. Mainly, Barton wants actors to be aware of their breath, where they pause during lines and what this means to an audience, the pace at which they speak, how they use vowels as opposed to 
consonants in the poetry, and how to use the poetry to its fullest emotional effect without overdoing it.

I found Barton’s advice in his chapter "Set Speeches and Soliloquies” to be particularly helpful. For example, he suggests "move and take the audience along with [you]" (Barton 109), which he then describes how to do. This provided a base to approach Edmund's famous soliloquy in 1.2. Other valuable advice for Edmund included: “changes from rhythm to prose and vice-versa often contain hints to an actor about character” (Barton 85) and actors should play the rhyme of the poetry rather than dodge it (Barton 157).

\section{Alexander Private Lessons}

At the end of my second year in the MFA program, Chair Nefertiti Burton asked if there were any areas of training that I felt like I had missed. I replied that I wished I had more Voice and Movement training. I had received feedback from many professors that my voice and body needed work to be able to "fill the space." I had no idea what that meant beside "be louder and take up more space," or "project your energy more into the space and audience." Soon, I was told that third-year students could take Voice the following fall with the second-year students. Later, I learned that my new teacher was Professor Rachel Hillmer, who would teach Voice with an Alexander Technique approach. This was to be the final piece of the puzzle that gave me the confidence and ability to approach Edmund using a consistent, reproducible method.

The Alexander Technique is a system developed by F.M. Alexander that helps practitioners relieve unnecessary muscular and mental tension. At my first Voice class that fall, I had no idea what to expect except that I would be behind the rest of the class 
after missing two weeks because of Disgraced. Upon meeting Professor Hillmer, we briefly talked about my goals for the class. My main concern was improving my voice for King Lear. Since it was already September and King Lear went up in November, I thought we needed to start working now. After two years of graduate school, I realized that confidence, arguably the biggest part of a successful performance for me, comes from preparation, and a hell of a lot of it. She agreed. We would meet that Friday morning outside class for an hour in the Belknap Playhouse, the space where Lear would be performed since it had its own acoustic challenges.

The first session was very different than what I expected. Rather than jumping straight into a voice-warmup, Professor Hillmer had me walk around the stage and eventually asked me to speak a few words. I had no idea what was going on. By the end of the session, I was still walking and speaking, but just barely. Apparently, I had a slew of bad habits that had compounded over years, which Professor Hillmer assured me the Alexander Technique would help "undo," a term she kept using throughout our sessions, one that means the "opposite of 'doing'." One of the cruxes of his technique is that practitioners do not actually “do” anything. Rather, they think “directions” (specific, targeted thoughts) to themselves, which in turn have a physical effect on the body due to the human body's psychosomatic relationship. At first, I felt this was a New Age concept that might or might not work, but recalling how skeptically my statements on the benefits of meditation had been taken before by students of mine, and how that frustrated me as a teacher, I wanted to give $100 \%$ effort so I jumped to Professor Hillmer's instructions. To my surprise, by the end of the first session I noticed a change in my posture and, thus, my voice. For the first time ever, I felt no strain filling the performance space with my voice. 
Professor Hillmer made a very important point that was to change my concept of the voice: It is not volume or diaphragmatic speaking that makes an actor fill a space, it is resonance. Resonance comes naturally through proper use of the body and voice, which Professor Hillmer explained was the main application of the Alexander Technique: to reset the body to its natural state, undoing a lifetime of bad habits along the way. I left the lesson intrigued, mystified, and excited for more.

As the weeks progressed, Professor Hillmer and I met every Friday until late October before the production opened. We covered a host of incredibly helpful topics such as: how to properly walk in the boots I was wearing in the show, how to walk on a raked stage without losing good use of the body, and how to use my voice's natural resonance to fill the space, the focus of our work. We eventually took all these and combined them into monologue work.

I made valuable discoveries in this setting that I attribute to the intense, laser-like, near-meditative focus that the Alexander Technique demands. It is mental as well as physical and benefits accrue in both domains. One of the main acting benefits was that it fired up my imagination in regards to Edmund's relationship with his father, helping to construct a backstory for them that benefitted my performance. I created a tale of unwed pregnancy, shame, abandonment, longing, and desperation for Edmund, Gloucester, and Edmund's mother. It solidified that the play is about Edmund in the way that actress Harriet Walter wrote about performing The Duchess of Malfi. In her article, Walter expresses her opinion that the tragedy could actually be the tragedy of a different character besides the title one, such as Edmund in Lear: "The play is perhaps the tragedy of Bosola. For me, anyway, he emerged as a kind of Everyman, who undermines his own 
capacity for good through cynicism, and comes to enlightenment too late." (White 96) In the same article, she states, "[Bosola], having suffered hardship, punishment, and betrayal is a disillusioned man, whose low expectation of himself and his fellow man become a self-fulfilling prophecy." (White 96) While the statements do not mirror Edmund exactly, they informed me tremendously.

These mental discoveries affected my voice and physicality as Edmund. For example, after working in regard to the raked stage, I observed that Edmund tended to bend his knees and lean forward when speaking to the audience during his soliloquies and asides, which combined with the already tilted effect of the raked stage, was intended to make the audience feel included as conspirators. My previous training using Patsy Rodenburg's book, The Second Circle, merged beautifully with the new Alexander Technique. Rodenburg posits three “movements of energy” (Rodenburg xiv), First Circle, Second Circle, and Third Circle. In the First Circle, “energy is inward-moving, drawing energy towards the self.” (Rodenburg xiv) In the Third Circle, “energy is forced outward toward the world in general.” (Rodenburg xiv) It is in the Second Circle where “energy was focused on a specific object or person and moved in both directions: taking in and giving out” (Rodenburg xiv). Rodenburg writes that actors should strive to be in this circle. With this concept in mind, I would speak to the audience. Whenever breaking the fourth wall in previous Shakespearean productions such as Othello, however, I never felt truly present. Sometimes, I felt as if I were speaking at the audience rather than to it. Thanks to the Alexander Technique, I could accomplish speaking to it both physically and metaphysically by giving energy to the audience, taking their energy and using it in a cyclical fashion to make them feel like participants 
while using this to fuel my performance, while maintaining good use of my instrument allowing it to resonate as never before. Finally, I understood what it meant to fill the space.

I cannot stress enough the importance of the Alexander Technique in my progression as an actor. It helped solve numerous voice and physical problems, such as lack of resonance, lack of a high-degree of specific control over my body and voice, and a unified theory of body, voice, and mind that allows the imagination to run free.

\section{Edmund's Movement}

During rehearsals, one of my goals was to find the way Edmund moved differently than I. I approached this a variety of ways: "physical dramaturgy" of the time-period via paintings; "animal” movement exercises; and research into the manners and formalities of the period for Edmund's socio-economic class. Through the combination of these, I could find a way of moving unique to Edmund outside of my habitual physical patterns. The production's costume designer, Zhanna Goldentul decided with the director to set the production in the Romantic Period (1780-1840). Thus, the first place I began my research was in Bari Rolfe's book, Movement for Period Plays, which details specific movements and gestures for different periods.

Rolfe describes the Romantic period as a short one, with overlap between the existing classic and emerging Romantic stylings, as the latter overtook the former. The major political shifts of the era contributed to the changing styles. The major theme of the Romanticist era was "a passionate return to nature, character, soul, and truth, and a rejection of rigid form and intellectualization" (Rolfe 89). Immediately, I felt at home as Edmund due to the links between him and nature as pointed out above. Individuality, 
human rights, and beauty replaced uncomfortable, restrictive clothing, artistic barriers, and intricate fashions. This reminded me of a trait I saw in Edmund: the shedding of social rules. As Rolfe points out, this was due in part to the influence of the Napoleonic Wars, which intermingled various European cultures, including the British and French. In fact, "the center of men's fashion moved from Paris to London, where it has remained" (Rolfe 91). This gave me even more access into how Edmund would dress, walk, and carry himself. As I read Rolfe, I began to learn that the era of formal self-control was fading out, as "l'âme sensible" the, "the sensitive soul and spirit," began to freely display passion and overt emotionalism. This observation also lent itself well to Shakespearean plays, which lend themselves to big and bold physical and vocal choices. Keeping in mind that the play was to be staged in The Playhouse, which is a large, classic, proscenium stage, I felt like the circumstances were perfect for large physical choices. However, Pennington had told me that she had cast Edmund as a soldier in the King's army. How, then, to reconcile the stiff formality of my imaginative military education with the free-spirited themes of the period? The answer was to come later, with physical dramaturgy and animal imagery-based exercises.

Physical Dramaturgy was a term I first heard in Dr. Jenn Calvano's movement class my third-year. It refers to a practice where actors supplement scholarly research on the time-period with research into paintings from and about the era. The paintings show bodies at rest or in motion. If possible, the paintings' subjects should be of a similar socio-economic class as the character. From there, the paintings' subjects can be studied for details such as their attitudes, posture, and, their manner of movement, rest, and so on. Essentially, a performer can develop a physical well of inspiration from historically 
accurate documents. For Edmund, I focused on paintings of soldiers in the Napoleonic era. Originally, I procured eleven images, and five of them resonated with me on an emotional level. I studied the way the subjects held themselves, their attitudes as discerned from body language and the expressions on their faces, and the way they were moving, if they were. The position of the soldier's feet was very helpful and set me back to Rolfe's book. After further research, I realized that soldiers of the era would stand in ballet positions, specifically third position when at rest. I began standing that way during rehearsals, which helped me feel at place in the era and the character. One image, that of Sean Bean in the Napoleonic Era-set TV series Sharpe, helped immensely. It chronicles the adventures of a British soldier, played by Bean, during the Napoleonic Wars. The look on Bean's face, his cockiness, swagger, boldness, and long hair - all resonated with my conception of Edmund. This gave my imagination a sort of mask I could step into when playing him.

Another type of physical dramaturgy can be found by studying animals. The practice for actors goes back centuries to Commedia d'ell Arte, in which certain archetypical characters took on animal-like aspects in their physicality: Harlequino as a cat, for example. I began to study Edmund's text to find animals I could associate him with, which might provide points to delve deeper into the character. I ruminated on what Edmund might be linked to. In some sections of the text he mentions bears (“...my nativity was under Ursa Major...” (I.ii)), but that did not really resonate with me. Edmund refers to his behavior as rude and lecherous because he was born under Ursa Major, but I was going for a more suave Edmund. This was a mistake; ignoring the text to fit a preconceived notion. As I ruminated, one of my cats began rubbing against me 
demanding attention. As I went to pet him, he moved just out of arm's reach, trying to force me to move closer. And then, it clicked: Edmund was a cat. I saw the connection in his luxuriousness, the way a cat enjoys sleeping in the sun, or stretching, or just relaxing; in his flirtation, or the way cats seem to only pay attention to a person when they need something, like food or comfort; and in his confidence, the "look at me" yet coy attitude that my cat had when he wanted me to pet him, yet sat just out of arms reach. All these qualities made sense when applied to Edmund's text. Earnestly, I began searching for pictures of cats that might work with Edmund.

After researching these, I focused on a specific species: the jaguar. Some jaguars are dark black, and use this to camouflage themselves in the dark of the night when hunting. They are at the top of the food chain and use opportunity and ambushes to hunt their prey. Although solitary in nature, they are incredibly dangerous one-on-one because of their powerful bite. All of these qualities appealed to me, but it was the dark black color of the Jaguar that fired me up most. I have long black hair, and the similarity just clicked. I began to look exclusively for pictures of jaguars. After finding many, I showed Professor Calvano my research. We whittled the pictures down to those that truly impacted me. We set a date to work on Edmund's soliloquies using the pictures I had curated.

Professor Calvano asked me to prepare to work Edmund's first soliloquy. We met Friday morning, October 29th, 2016. We began with me moving on the ground as a jaguar, and Professor Calvano observing and offering notes. Next, we took the monologue and combined it with improvisational movement based on jaguars, which allowed me to get out of my head and fully apply the movement exploration into practice. 
After doing the improvisations a number of times with feedback from Calvano, we discussed what we had found. I realized that Edmund was immature and enjoys bragging that is founded in naivety and youth. For example, he repeatedly brags to the audience after his victims leave the stage. Calvano also posed an interesting question that I had not considered: Does Edmund learn he is to be sent off when Gloucester tells Kent that Edmund is leaving soon after Lear divvies up his kingdom? How does that affect him? This question opened a door that gives Edmund ample justification to explain his egregious actions throughout the play. From here Calvano asked me to start applying in rehearsals the movement we had discovered in this session. From there, it grew even more.

\section{Edmund's Music}

Another great tool suggested by my former teacher, Corey Parker, was the effect of music on acting. While I had inherently felt this, Parker encouraged his students to make playlists that might inform the character and to listen to them backstage during a performance. I began curating a playlist for Edmund when rehearsals started in September. The first song that really stuck was "To Forgive" by the Smashing Pumpkins. The lead singer addresses being a

"bastard son of a wild-eyed child"

who

"sensed his lows, before [he] even learned to speak ..."

and,

“And I remember my birthdays / Empty party afternoons won't come back 
These brought images to mind of a small child, abandoned by his father, waiting for friends who will never arrive. The melancholy and mournful tune helped capture the angst and sadness I felt Edmund would have towards his father and his childhood in general.

The song informed Edmund's motivation and character and gave me a jumping off point, a type of backstory that began informing other songs on the playlist. The band captured the feeling Edmund has before the show starts, perhaps even the feeling Edmund grew up with as a teenager. Since Edmund is a young man, this feeling would feel recent and fresh. Interestingly, the song did not make it into my final backstage playlist; it was replaced with songs chosen specifically to sustain energy or trigger an emotion or feeling.

As rehearsals progressed and I saw the arc I was constructing with Pennington, other songs naturally slid into place. I would listen to each before a particular scene as close to my entrance as possible. The songs were chosen specifically to circumvent a problem I encountered while rehearsing and performing the title role in Othello, two years earlier in the same venue.

Prior to the "killing scene" at the end of Othello, I would be backstage being misted with water from the costume crew to make it look like I had been in the rain. To "get myself into the right frame of mind" to play a character who's about to murder his spouse, I asked the costume assistant to do more than mist me with water: but to pour icecold water on my head and back. The shock, I hoped, would take me to a higher plane of awareness. Simultaneously, I tried to recall a particularly sad moment from my life to capture the "heavy somberness" of the moment. I never felt like I sold that moment on 
stage, and at the time I could not figure out why. It was because I was trying to play a "mood" rather than an actable goal.

I now know that trying to play a mood is a huge "no" for actors. Actors can only play an action in pursuit of a goal, never a mood. But, an actor can carry energy into a scene, which may bring with it a certain mood. This is what I was searching for during Othello with the ice-water, and what I found with Edmund through music. Songs can influence a character's walk, tempo, and mindset, for example. Music can also help reveal vulnerability, which assists the actor's work. That's why these songs were chosen: because they had a visceral effect on me that I could carry into my work.

One of the main artists who stood out to me during this stage of rehearsals was Kanye West. I modeled much of Edmund's attitude and overall character on West's behavior: that of a cocky, bold, young man who thinks he is, and might well be, a "genius". Although only one of West's songs made the final playlist, his music and persona had a large influence on my portrayal. While researching songs I thought, "What type of person brags about coming from nothing after having a bad lot in life, and then relishes in the drama and decadence of the actions they had to commit to get what they wanted?” The answer was: modern day rappers, specifically Jay-Z and Kanye West. Jay-Z has a great deal of "boldness" and "swagger," but West set my imagination into high gear. He was subjectively cockier than Jay-Z, with more natural talent but less credibility. This seemed like Edmund, who is smart enough to have schemed his way into fortune, but does not have the paternal backing that Edgar does. The similarities were glaring. Armed with a playlist and an inspiring role model, I felt prepared and confident to perform. 


\section{Environmental and Continuity Exercises}

One of the biggest lessons learned during Disgraced came from Parker’s note that I needed to do better fourth wall work. This refers to the imaginary fourth side of a proscenium stage beyond which the audience sits. It is crucially important, as Parker pointed out, that actors have a specific image or fourth wall for each new environment they interact with during a play. This allows actors to have the confidence to direct their energy towards the audience, which makes it feel more included, energized, and engaged. Audiences can also tell subconsciously when an actor has not done this work, and is not confident enough to gaze into the auditorium for fear of not knowing where to look because they do not know what they are seeing. As stated previously, Parker noted that my work suffered from this exclusion, in this role.

Before Parker pointed this out, I was unaware of my tendency to close off the audience. I had done fourth wall exercises before, but had never habituated them into preparation for every role. This stemmed in part from my experience in Shakespeare, strangely enough. As Barton says, we "point-out to the audience" (Barton 54) in Shakespeare, that is, the characters freely break the fourth wall and interact with the audience. I usually did not run into a problem looking into the audience because I had mostly performed Shakespeare in my career and my habit was simply to look at a specific audience member. No director pointed out that I was not being specific enough in my visual imagery for the fourth wall. So, I did not do specific exercises to work on this detail during my preparation. I can only recall one time in the past five years when I undertook this level of detailed work with a character's environment, as Lysander and Francis Flute in Threepenny Theatre's production of A Midsummer Night's Dream in 
2014, in Memphis, and interestingly, I consider that performance as one of my strongest ever. Now I understood why it was important to include these exercises and this work every time, even when doing Shakespeare: It grounds the performance in an imaginative reality, giving actors more confidence and reducing self-consciousness. Rather than losing touch, however slight, with the world of the play when addressing an audience member, hopefully now the audience member would be transported with me to the world of the play. The effort is small, but the reward is large. I hired Parker to give me notes on my strengths and weaknesses, and Lear was the time to address the weaknesses he noticed. How?

For Midsummer's environmental and fourth wall exercises, I would go into the theatre on a dark day, near or after the midpoint of the rehearsal period, and sit alone. I would meditate and focus on the given circumstance of the scenes for which I wished to construct an imaginary environment. I would explore the space physically and imaginatively while I constructed a full, 3-D world of the character's total environment, including natural sounds like birds, and weather, like storms to fit the blocking. Sometimes I would bring my journal and write about a day in my character's life. I constructed the environment this way. However, I did not do this for every single scene, just those I felt needed the extra commitment imaginatively. For Lear, I decided to construct every environment with which Edmund interacted.

I went into the Playhouse near the end of rehearsals on a Saturday afternoon when I would be alone to work undisturbed. I chose to wait towards the end of the rehearsal process for a few reasons, but mainly because I wanted any kinks between the set or any set pieces and my blocking to be worked out. The design looked intricate and grandiose 
on paper, and I wanted to be sure of my movement in it before I committed to constructing an imaginary environment I did not want to change later. Like three years prior during Midsummer, I meditated to focus on the world of the play and character, and I began to imagine the environment. I went through each Edmund scene and mentally and physically explored the space. I traced my blocking to make sure my imagined world did not contradict Pennington’s direction. During this process, I noticed something interesting: I had the choice to stretch the fourth wall to various depths, depending on the scene, and the large size of the Playhouse invited me to create expansive, bold, and epic environments, which I thought were apt for the material.

After I was satisfied with my choices, I sat with my journal and did something I had not done for Midsummer: I sketched each environment as detailed as I could. I sketched seven environments for nine locations: the ceremonial room from I.i (Fig. 1, pg. 45), Edmund's lodging in I.ii and II.i (Fig. 2, pg. 46), the exterior of Gloucester's residence in III.iii (Fig. 3, pg. 47), an interior room in Gloucester's residence III.vii (Fig 4, pg. 48), the interior foyer space of Goneril's residence IV.i (Fig. 5, pg. 49), the military camp of Albany and Cornwall's forces from V.i (Fig. 6, pg. 50), and the interior of the military camp of Albany and Cornwall's forces, post-battle from V.iii (Fig. 7, pg. 51). I did not sketch an exterior of Gloucester's house where Gloucester tells Edmund of a letter from Lear he has received in III.iii, and an interior of Gloucester's house where Edmund tells Cornwall of Gloucester's betrayal in III.v. I did not sketch these because I ran out of time, and they were the easiest to imagine because enough elements were contained in other sketches of the interior and exterior of Gloucester's house for me to feel confident in them. 
I tried to be as detailed as possible. This is a note every acting teacher gives to students for a practical and obvious reason: every detail matters and can influence a scene. Therefore, be as specific as possible. This also holds true for the physical exploration of the exercise: It is not enough just to imagine the environment; actors can go deeper by imagining the temperature, the quality of the light, the sounds the character might hear, the weather of the setting, and so forth.

The effect of the sketches on my performance was astounding: I could look into the audience with confidence and specificity. With such detailed imaginary environments, I could pick when and whom to look at in the audience. Details filling each environment helped tremendously: What are the paintings on Gloucester's wall? When Edmund looks out a window, what is the view? What is the floor tiling like in Gloucester's house? In Edmund's lodging? I also gave some of the buildings histories, for example: Edmund stays at Gloucester's house in a converted doctor's lodging and study since Edmund does not live with his father the majority of time. What objects are in the former doctor's office? How does it affect Edmund to be lodged apart from the main estate? All my choices became more specific and nuanced as a result of this work.

After sketching the details of Edmund's environment, I ran into another logical question: Where does Edmund go after he exits the stage, and what does he do? It is common for actors to work on a "moment-before" their characters' entrances, but few teachers talk about the importance of knowing what happens after exits. Like the fourth wall work, I needed to fill in these gaps. Within my journal, I once again created an entire story for Edmund off-stage. This was crucial because so much of Edmund's story is tied up in the off-stage activities of other characters. For example, much of what the 
audience sees happens to Edmund from the point of view of Goneril and Oswald, such as delivering Goneril's letter to Edmund via Oswald. What is Edmund doing, meanwhile, to achieve his goal behind the scenes?

I identified four places and questions that would help me to accomplish this work: where does Edmund come from before I.i (essentially, Edmund's backstory)? Where does he go after I.ii? What happens on the way to Albany's (after III.vii)? And, where does Edmund go after Goneril instructs him to go to Regan and Cornwall (IV.ii)? These seemed important to flesh out, because Edmund schemes between these scenes, and when we see him at each turn he has a new plan or action. The effect was, again, tremendously helpful. I could specifically imagine what Edmund did after he left each scene that would help me begin my next scene with a driving goal. I have no doubt this gave my performance drive, urgency, and focus that was probably lacking in previous performances. It was also incredibly helpful to think through a specific plan to trap my brother and to find out how Edmund came to the conclusions he did about when, where, and how to snare Edgar in his plot.

\section{Challenges Faced during Rehearsals and Performance}

One of my biggest challenges was the need to explore too much. A classmate once said, "Dig a well, do not dig trenches." What he meant was once an actor finds something that works, plumb its depths. Dig a well into truth (down), rather than exploring trenches (to the sides). I encountered this problem during rehearsals, and I think it was because of Edmund's first soliloquy.

Being one of Shakespeare's most famous, it has weight, history, and creates high expectation. In this soliloquy, Edmund reveals the reasons for betraying his family. The 
issue I ran into was its intended effect: I could deliver the lines as if Edmund were a typical gleeful villain, engaging in machinations while twirling his figurative mustache in delight. This was how I had seen the role played. Or, I could try to show the depths of Edmund's emotional pain that motivates his actions. I thought this made Edmund more sympathetic to the audience. It made him a type of anti-hero.

The problem I ran into was the direction. Repeatedly, Pennington would ask me to take more enjoyment in Edmund's villainy, urging me toward the exact portrayal that I hoped to avoid. I strived to be as open as possible, but Pennington almost always had to direct me to get where she wanted. I habitually began rehearsals with a quality of righteousness that I thought Edmund deserved, and had to be directed to a more gleeful place of villainy.

Worried about my performance, I tried to work on the soliloquy even more, which resulted in more anxiety. I took the soliloquy to one of my acting classes when the teacher offered an opportunity for those of us in Lear to work our monologues. The teacher and I agreed it was more interesting to play up Edmund's justification for villainy rather than his enjoyment in being a villain. That evening in rehearsal, I again delivered the soliloquy full of pathos and angst. And once again, Pennington asked me to take more delight in just being bad.

Eventually, this came to a head during tech week when she addressed the graduate students in the production. A few of us, she said, had been exploring too much rather than taking direction and building on it. While she empathized with us as actors wanting to explore, the time had come to end such exploration. The show had too many characters in too many worlds, and it was time to unite behind one vision: the director's. 
I immediately saw how the time I had spent exploring different pathways to Edmund's psyche and emotions could have been spent finding truth within the direction, however much it might contradict my vision. The director's vision should take precedence over all others. I had erred in working on the monologue with a teacher who disagreed with my director rather than trying to do what my director asked. Thankfully, we still had some rehearsal time left, and it was not a moment too soon that I decided to invest fully in what the director wanted.

Because of the amount of preparation I had done on the role starting the previous summer, I had felt I could be a little more luxurious in exploring than usual. Apparently, I got carried away. After satisfying my ego-driven decision to explore, I bought into what the director was asking me to do 100 percent. When my cast mates did this as well, we suddenly soared as an ensemble. Moments were clicking where they had not before, and it seemed obvious in retrospect: How could parts of the show work or flow smoothly if the person's whose vision is in charge is not being embraced by everyone in the cast?

Another problem I faced during rehearsals that carried over into performance was difficulty keeping focus. The show ran two and one-half hours, which is a long time to stay in the demanding zone that is required cerebrally for good acting. Thankfully, my exercises from the summer anchored me: a regular warmup, followed by meditation. For Edmund, I added a new tool: a playlist to listen to backstage that fed my character.

My warmup is the foundation of my performances. I loathe acting without doing my regular voice warmup. The entire routine lasts fifteen to twenty minutes and is derived from the teachings of Elsie Fogerty, the founder of London's Central School of 
Speech and Drama. I have done it before every show for three to four years. I always do it in the space, on stage.

Warming up this way does two things: it first allows me to get over any selfconsciousness I might be carrying by forcing me to warmup in front of others. Second, it lets me test my voice before the audience arrives. This crucial check-up for my instrument lets me modify and tune it to suit the venue. After my warmup, I am focused on the performance ahead. It allows me to transcend my daily life into a more focused and readied state, more suited for performance. It gives me the confidence I need to have a full-bodied voice required for the theatre.

Even so, it was difficult staying focused for the entirety of the show, this time due to the length and intensity of the production. I helped my focus and concentration by meditating immediately after my warmup, but I also noticed during the dress rehearsals that I was still losing my focus and energy around intermission. The playlist ended up being the tool that solved this. 


\section{CHAPTER FOUR \\ ANALYSIS AND CONCLUSION}

\section{In-Performance Analysis}

After committing to Pennington’s vision, the show finally “clicked” for me. Having her explicitly direct us took the pressure off. It relieved the anxiety stemming from my fear and ego-based desire to create a performance that was "good.” Yes, it was still up to me to make the role my own, but the route I was now pursuing was given to me, which made it easier to walk that route as if I were given a map.

Meditation allowed me to be focused and present, what many people call being "in the zone" or "in the moment." This focus and awareness allowed me to "play" on stage as Edmund. After meditating, my mind was not focused on preparation I had done. It was, rather, "in the moment," able to act and react to immediate stimuli from other actors, lighting cues, and sound cues. I could fully immerse my imagination in the world of the play without being distracted. The massive amounts of preparation since the summer paid off. I was intimately familiar with Edmund's text, his environments, and his relationships. Almost anything an actor might want to know to play this character, I had researched.

Due to my exercise routine, I now had a larger breath capacity that helped me handle longer monologues and soliloquies. My back, legs, and core felt ready to work on the rake of the stage. I rarely felt physically tired after the show, a marvel, considering I had 
to lead fight calls, the production lasted two and one-half hours, and the energy to repeat that performance daily was tremendous. My body felt like Edmund's might feel, and as others in the cast succumbed to fatigue and sickness, I realized the importance for actors to be physically fit.

The fourth wall work was now paying dividends. Parker was right: By not having a specific fourth wall constructed, I had cut myself off from the entire audience. By constructing such an image, my energy was now free to fill the entire space, and the audience hopefully felt more included. The work gave me enough confidence to face the audience while maintaining my character.

Something that never quite felt right was Edmund's opening soliloquy, both despite and because of my focus on it. I had taken pains not to work it excessively during rehearsals, but my idea of Edmund was altered late in the process after Pennington's talk. So, ironically, despite my diligence regarding overpreparation, I ended the process focusing on the soliloquy intently. Even though Pennington had given me a map to follow, I struggled. I do not think I ever delivered the monologue to its full potential. It is incredibly complex and full of interesting poetical twists and turns. While I did not particularly excel in my performance of the monologue, I finally understood what older actors meant when they say: "Technique will carry you through.” On nights where my inspiration was gone, it was rote rehearsal work and hours of practice that took over and allowed me to make it through a performance passably. If I had not taken Pennington's direction, this would have gone even more poorly. Because she gave me a very specific image of what she wanted, and because I had put in so much work prior to performance, I could use her direction as posts on which to build my performance. 
As I noted earlier one of my problem areas was my voice and how to "fill the space." Thankfully, the Alexander Technique training helped immensely. By the time the production opened, I had a clear and resonant voice that could be heard anywhere in the house. This progress would not have been possible without Professor Hillmer. This reinforced how collaborative theatre is. I would not have been able to afford to hire a private Alexander Technique coach to work on my voice. It is only through my guardians, mentors, and teachers that I have gotten this far.

An interesting habit I discovered during performance was how my physicality changed during the show. Until Professor Hillmer pointed it out, I did not even notice this was happening. She noted that when I was speaking to other characters where Edmund is mostly lying, such as in I.ii with Edgar, I had one type of physicality: stiff, still, upright, and formal. However, whenever I spoke to the audience directly breaking the fourth wall when Edmund reveals his inner thoughts and truth, Hillmer said that I would bend my knees more, loosening my posture, lean forward, and let my voice drop. That was incredible to learn from her. It reinforced that my body was subconsciously responding to my internal cues, which meant that I had a responsive instrument! I had not worked on changing my physicality and voice between talking to whomever was on stage as opposed to the audience, so it was nice to know my instrument was tuned enough to naturally do that for me. After three years of training, it was rewarding to see some results.

As for my playlist: "The Effects of Music on Acting" could be a thesis unto itself. The final playlist consisted of:

1. "Closer" by Nine Inch Nails (preshow) 
2. "Hell of a Life" by Kanye West (2.1)

3. "Aenima" by Tool (eventually cut, but briefly was used for a few shows around

4. "Five Minutes Alone" by Pantera (replaced the Tool song for 3.5)

5. "Blessings" by Big Sean (intermission)

6. "Ten Bands" by Drake (intermission)

7. "Mouth for War" by Pantera (4.2)

"Closer" by Nine Inch Nails and "Hell of a Life" by Kanye West helped me capture Edmund's attitude prior to his decision to betray Edgar. They provided fuel to motivate Edmund's overall objective, which I had decided was “to be loved.” The incredibly sensual and lusty sounds of "Closer" helped me capture the explosive seductiveness of Edmund. "Hell of a Life" helped me find the bravado and overall shamelessness of Edmund and also the quality of sexual decadence that Pennington starts the show with as Edmund appears onstage chasing and catching a courtesan. The first line from that song, "I think I just married a porn star" removes any traces of selfconsciousness. That helped me overcome my natural shyness since Edmund's delightful villainy is quite opposite my own personality.

"Five Minutes Alone," by heavy-metal artist Pantera, preceded my entrance to 3.5. Scene 3.5 is where Edmund gives the Cornwall letters, from Gloucester to Lear, intimating that Gloucester will help usurp Cornwall and the Albany's rule in favor of returning Lear to the throne. I chose "Five Minutes Alone" because it has a hard beat and determined guitar melody. I think it is that quality of "determination" that appealed to me in this instance: Edmund was struggling with giving up his father to Cornwall, so the 
determination of the song combined with the inherent anger in the lyrics helped push Edmund over the edge of morality, into what essentially amounts to patricide.

"Blessings" by Big Sean and "Ten Bands" by Drake were chosen as songs to listen to during intermission. I started listening to intermission music after the first show, because I felt myself getting out of "the zone" during dress rehearsals and that first show. They were chosen because of their artists' cocky and boastful attitudes. At intermission, Edmund is feeling good about his scheming, having gotten rid of his brother.

A steady rhythm, somber violins and string instruments, and a steady drum beat give the song "Blessings" a sound that I would describe as "fated," as in, the artist makes it seem as if his success was written by the Fates themselves and that there is more to come. "Ten Bands" has an aggressive "go get it" feel, combined with a feeling of victory, which helped me stay energized in the latter half of intermission.

Listening to "Mouth for War" by Pantera, before 4.2, the final climactic war-andaftermath scenes of the play, always got me in the mood for battle. This helped my "moment before" as Edmund, who knows he is about to fight in a large battle where he could die. Since I have never approached anything remotely like that, listening to a heavy-metal song about war seemed like a good way to put myself into that mindset. It worked. The songs helped me stay focused and energized more so than without them. Music was a very helpful tool in my process.

\section{Thing I Missed and Where to Go Now}

During the performance, I was constantly dogged by this line: "But what art thou / that hast this fortune on me? If thou'rt noble, / I do forgive thee." (5.3) I could never understand why Edmund would forgive someone based on their nobility. After all, had I 
not just spent a few hours trying to subvert what nobility really is? Because I never figured this out, I simply said the line as believably as I could to Edgar. This was a big “no.” Never just "say things” as an actor. If I could go back, I would find a more specific tactic for this beat. Perhaps I should direct it towards Albany, rather than Edgar, as Capet suggests in his article (Capet 12)?

Perhaps the solution would be found in rephrasing Edmund's overall objective. A re-reading of Thomas's Script Analysis provides a clear structure for choosing and phrasing objectives that I followed loosely rather than exactly. Thomas's rubric for choosing an objective has five points: The objective must come from the character's goals, must be directed at the other characters, must describe the inner life of the character, must relate to the main idea of the play, and must be stated as "I want to [verb], in order to [statement of purpose].” Rather than simply stating Edmund's overall objective as "to be loved," it would be better to pursue something like "I want to steal my brother's land to find the home I never had as a child.”

Another problem was Edmund's declaration when he sees Goneril and Regan's dead bodies: "Yet Edmund was belov'd!” Again, I would like to go back to reveal more about the character than I previously realized. Originally, I delivered this line by saying it as believably as possible. I would like to re-examine why Edmund chooses to say this line. Capet makes a great point when he theorizes that the line is "an exclamation all the more touching when we recall that it may be the first time Edmund has ever felt loved.” (Capet 13) What a great choice! Actors can always go deeper.

Finally, I could have improved the delivery of the 1.2 soliloquy. While I finally understood what it means to have technique as an anchor, I could have focused on what 
Penningon was trying to do earlier. I need to remind myself to err on the side of caution when exploring, and to not get too tangential from the director's vision.

\section{Conclusions}

When I began my MFA program, I had one main goal: to leave with an acting technique I could apply to any role. This thesis has recounted my testing of the technique I developed over three years. Overall, I achieved my goal: I am leaving with a clear understanding of how to approach virtually any role, and I have also increased my knowledge of the mechanics of acting, theatre, and art.

When looking back on the technique, I can clearly see how all of the exercises I completed affect me. They are designed to give me the most valuable gift of all: confidence. This technique supplies many different types of confidence: confidence in my movement and physical actions through the animal research and physical dramaturgy exercises; confidence in my imagination from sketching the environment, developing a story for what happens in between scenes, and coming up with a character backstory; confidence in my textual analysis and delivery derived from John Barton’s Speaking Shakespeare and John Thomas’s Script Analysis for Actors Directors, and Designers; confidence in my instrument via meditation, Alexander Technique, and physical exercises; and confidence in my stage awareness from Patsy Rodenburg's The Second Circle. Taken altogether, I can clearly trace how I acquired the tools for this specific technique I have crafted from these influences.

Looking ahead, I need to continue to study, practice, and refine my technique. More problems will inevitably arise, but after three years of training, I feel prepared to 
tackle any problems that come up. And, of course, I can always keep adding more tools to my toolbox. 




Figure 1: The first environment the audience sees (1.1), where Lear renounces his throne. This is a bird's-eye view of the imaginatory environment created. The double doors drawn above were at the back of the house in my head, so that the windows and tiles overlayed the audience 


\section{Ute locations}

- Edmends loging $(1.2 \div 2.1)$



- 2ed stary lodgang, 1 it floor vas meitérs office. Foll of globes, makshelves, parchments. Staircase leads to apt. apontis -upstion is lezy. Suall, ove person bed. Elmuend can surnive on

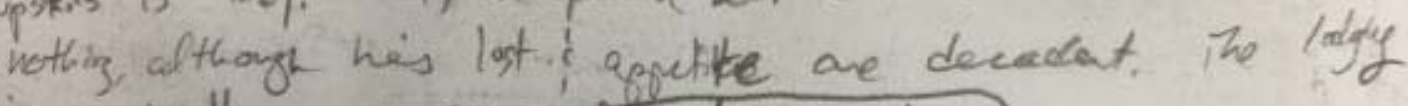
is an insolt.

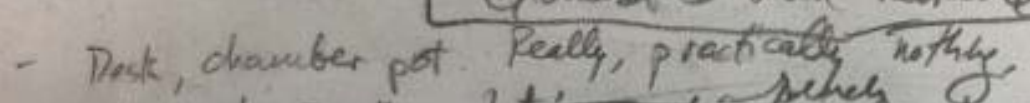

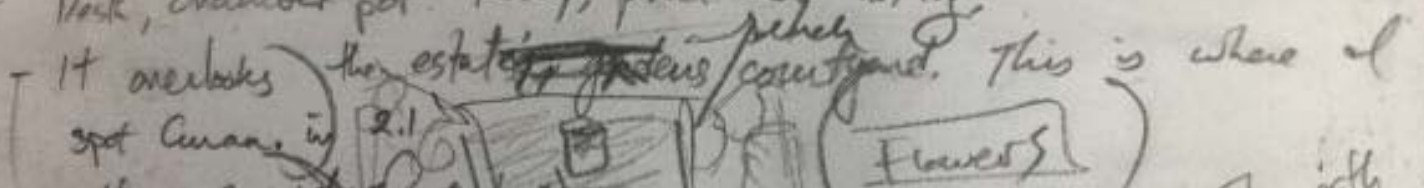



to of of yous

besn fictspredous

we" own

Figure 2: This is the view Edmund has outside of his window when he stays at his father's house. This is the imaginary environment I saw when looking out of the second story window in 1.2. In the lower right- and left-hand comers I wrote in where the different exits lead. Also, the description of the interior is written above the drawing. 


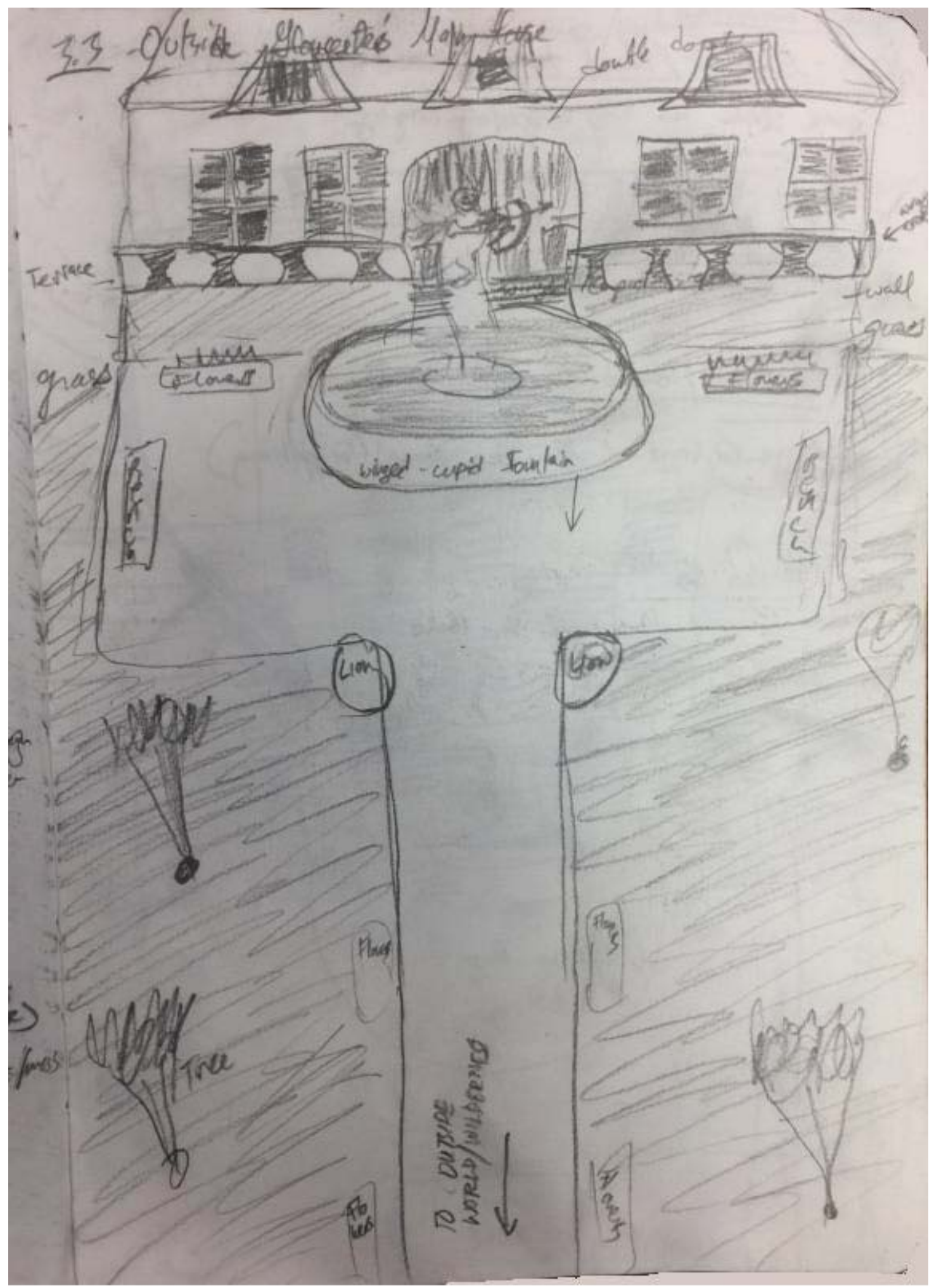

Figure 3: This is the exterior of the Gloucester residence, from the viewpoint of the theatre's house looking at the proscenium. The drawing of the exterior would be super-imposed on the set in my imagination. The residence is luxurious, but not opulent. Set-pieces were incorporated as trees, statues, benches, and so on. 


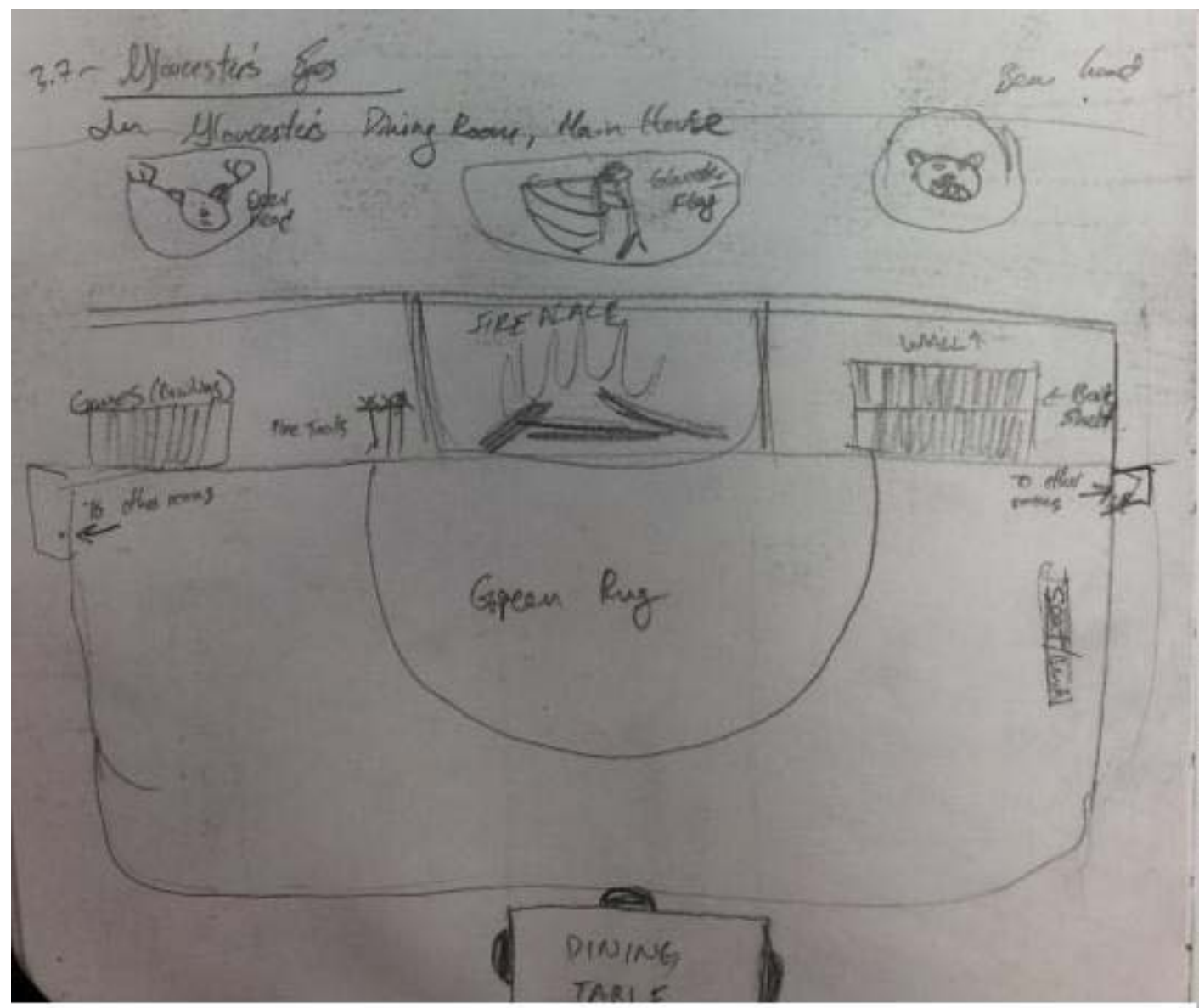

Figure 4: An interior view of Gloucester's dining room. This is an interior I imagined for the discussion between Regan, Goneril, Comwall, and Edmund right before Gloucester's eyes are ripped out. It is a fairly basic environment, with stuffed animal-heads, books, and even family games, used in happier times. 




Figure 5: An interior view of Albany and Goneril's residence, in the main foyer. This is the view I super-imposed over the house when entering from the upstage double-doors of the set. Albany's residence is very gaudy, with a gold-encrusted rug and portraits of Albany and Goneril hanging imposingly Green and gold were chosen for the tile colors, as those colors were what Goneril was costumed in during the show. 


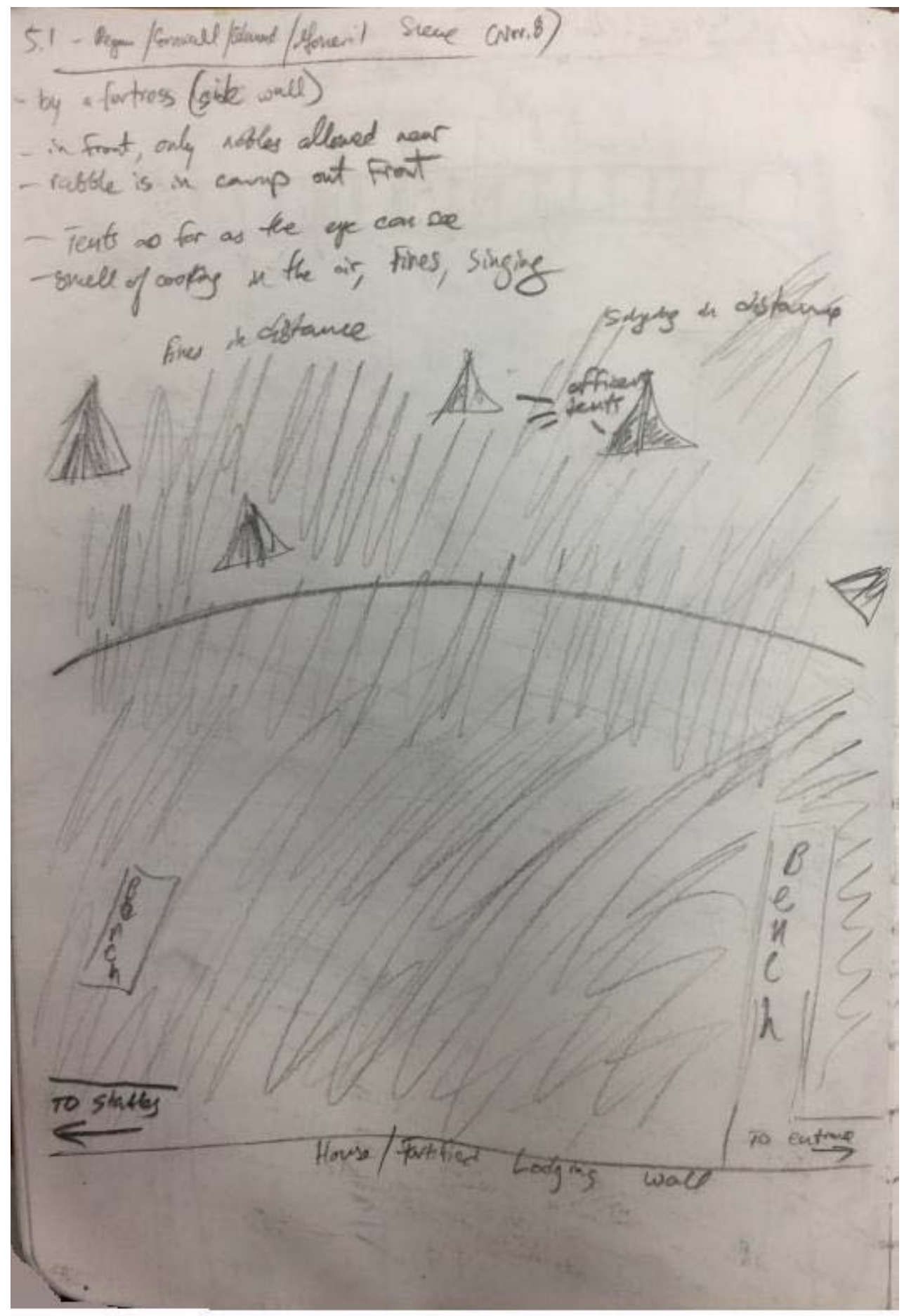

Figure 6: This is the camp for Cornwall and Albany's forces, from the view of an actor looking out into the house from the stage. The area at the bottom of the picture labeled "House/Fortified Lodging Wall" was where the main set was placed. The area in front of that label was imagined as a grassy field of tents, fires, and soldiers that stretched out from the stage into the back of the house. In essence, the imagined world was layered over the audience. 


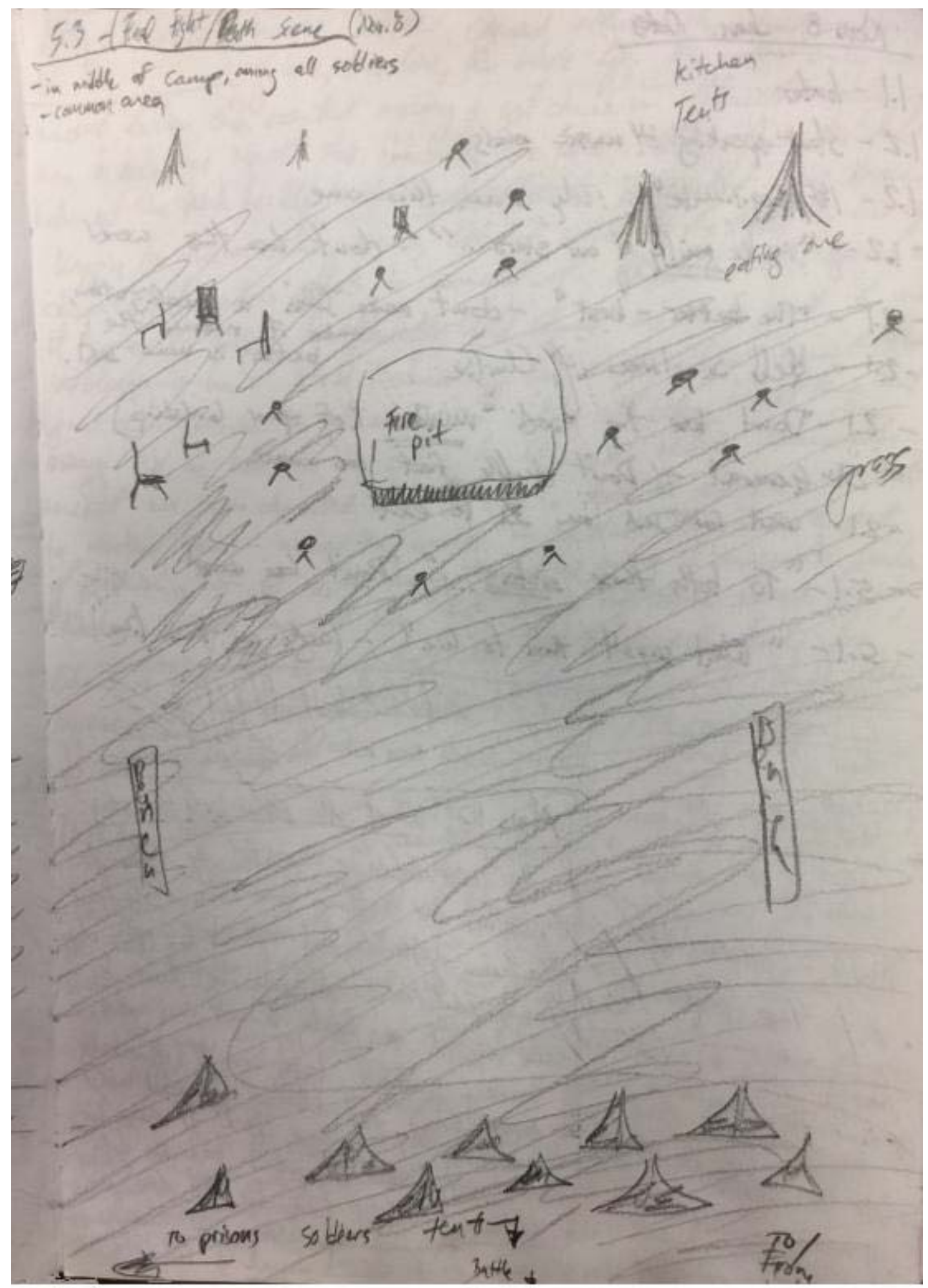

Figure 7: Another setting within the Cornwall and Albany army camp, post-battle where the final scene takes place. This area is more of a dining and gathering area for the soldiers, guaranteeing a large crowd for the final showdown between Edmund and Edgar. Again, the view is of an actor standing center stage and looking out into the house. 


\section{REFERENCES}

Asimov, Isaac. Asimov's Guide to Shakespeare: Two Volumes in One. 1st ed. N.p.: Avenel , 1978. Print.

Capet, Race. "It's New Mother Nature Taking Over: A Re-Reading of Edmund in Shakespeare's King Lear.” The Montréal Review, Feb. 2012. Web. 25 Apr. 2016.

Cohen, Robert. Acting One. 5th ed. Boston: McGraw Hill, 2008. Print.

Barton, John. Playing Shakespeare. 1st ed. New York: Anchor, 2001. Print.

Dean, Alexander, and Lawrence Carra. Fundamentals of Play Directing. 5th ed. New York: Holt, Rinehart and Winston, 1989. Print.

Donnellan, Declan. The Actor and the Target. St. Paul, MN: Theatre Communications Group, 2002. Print.

Freeman, Neil. Once More Unto the Speech, Dear Friends: Monologues from

Shakespeare's First Folio with Modern Text Versions for Comparison. Vol. 3: The Tragedies. New York: Applause Theatre \& Cinema , 2006. Print.

McNeir, Waldo F. "The Role of Edmund in King Lear." Studies in English Literature, 1500-1900 8.2 (1968): 187-216. Print.

Moulton, Casey Richard, "Presence and the actor's craft: Acknowledgements." (2016). Electronic Theses and Dissertations. Paper 2414.

Polatin, Betsy. The Actor's Secret: Techniques for Transforming Habitual Patterns and Improving Performance. Berkeley, CA: North Atlantic, 2013. Print.

Rodenburg, Patsy. The Second Circle: How to Use Positive Energy for Success in Every Situation: This Book Will Transform Your Life, Minute to Minute. New York: W.W. Norton, 2008. Print.

Shakespeare, William, Paul Werstine, Barbara A. Mowat, and Susan Snyder. The Tragedy of King Lear. New York: Simon and Schuster, 2005. Print. Folger Shakespeare Library.

Schulte, Brigid. "Harvard Neuroscientist: Meditation Not Only Reduces Stress, Here’s 
How It Changes Your Brain." Washington Post. The Washington Post, 26 May 2015. Web. 10 Apr. 2016.

Thomas, James Michael. Script Analysis for Actors, Directors, and Designers. 2nd ed. Boston: Focal, 1999. Print.

White, Martin. "Case Study: Harriet Walter on Playing The Duchess of Malfi." Renaissance Drama in Action: An Introduction to Aspects of Theatre Practice and Performance. London: Routledge, 1998. 88-100. Print. 


\section{CURRICULUM VITA}

NAME:

ADDRESS:

DOB:

EDUCATION

\& TRAINING:
Shaleen Tarun Cholera

Theatre Arts Department

2314 S. Floyd St.

University of Louisville

Louisville, KY 40208

Memphis, Tennessee - November 6, 1986

B.A., Theatre Arts

The University of the South

2005-09

M.F.A. Performance of Acting

University of Louisville

2014-17 